\title{
Blistering Indicator
}

National Cancer Institute

\section{Source}

National Cancer Institute. Blistering Indicator. NCI Thesaurus. Code C122195.

Specifies whether blistering occurred. 